\begin{tabular}{rr}
\hline \hline & $811.163 .41 ' 366.582 .6$ \\
811.16 & 366.582 .6 \\
$811.16 ’ 367$ \\
https://doi.org/10.18485/mks_srpska_slavistika.2018.1.ch19
\end{tabular}

\author{
Људмила В. ПОПОВИЋ ${ }^{*}$ \\ Универзитет у Београду \\ Филолошки факултет \\ Катедра за славистику
}

\title{
О ПАССИВЕ ПЛЮСКВАМПЕРФЕКТА В СЕРБСКОМ И ДРУГИХ СЛАВЯНСКИХ ЯЗЫКАХ ${ }^{* *}$
}

\begin{abstract}
В статье рассмотрены функции ППФ в славянских языках, связанные с выделением в семантике данной формы результативного и динамического значений в отдаленном от настоящего прошедшем. Особое внимание уделяется формам страдательного залога, соотносимым с ППФ, во всех славянских языках. Отличительной чертой данных форм является наличие нескольких конкурирующих вспомогательных глаголов в их составе. Формы страдательного залога с конкурирующими формами вспомогательных глаголов рассматриваются на материале современных славянских языков, а также церковнославянского языка древнерусского извода. Высказывается предположение об изначальной закрепленности результативного значения страдательного ППФ за имперфектом вспомогательного глагола и акционального за аористом, а также о постепенном вытеснении данной специализации темпорально неотмеченной л-формой вспомогательного глагола в тех языках, где она употребляется.

Ключевые слова: славянские языки, плюсквамперфект, страдательный залог.
\end{abstract}

\section{0 Функции плюсквамперфекта в сербском и других славянских языках}

Временная форма плюсквамперфекта (ППФ) в славянских и неславянских языках продолжает привлекать внимание многих лингвистов, исследующих ее как на материале отдельных языков, так и в типологическом либо сравнительном аспекте (см. Ивић 1980; Митриновић 1995; Молошная 1996; Загнітко 1996; Танасић 1996, 2005, 2005a; Козинцева 1998; Chinkarouk 1998; Крижанівська 2001; Thomas 2000, 2004; Сичинава 2003, 2004, 2013; Плунгян 1998, 2004; Петрухин, Сичинава 2006;

\footnotetext{
"1judmila.popovic@fil.bg.ac.rs

** Данная работа выполнена в рамках проекта 178021 Министерства просвещения, науки и технологического развития Республики Сербии.
} 
Шевелева 2007; Ярмак 2010; Попович 2012, 2012а, 2018; Movchan 2014; Мовчан 2015; Барентсен 2015; Храковский 2015 и др.).

По данным последнего исследования А. Барентсена (2015), временная форма ППФ активно встречается в болгарском, верхнелужицком, македонском, хорватском и сербском языках (Барентсен 2015: 153-154). Автор также указывает на то, что в современных сербском и хорватском языках выбор данной временной формы чаще всего является факультативным (ibid.). То же можно сказать и о ППФ в словенском, украинском и белорусском языках, где он употребляется гораздо реже, чем в болгарском, македонском, сербском и хорватском. Факультативность ППФ отмечается также в словацком языке, прежде всего имеется ввиду возможность его замены формой неопределенного прошедшего времени (Horák 1964: 290, 294). В чешском и польском ППФ можно считать изжившей себя формой, встречающейся в стилистически отмеченных контекстах, что связно с исчезновением в данных языках других претеритальных форм (ibid.). В академических грамматиках современного чешского и пољского языков ППФ не выделяется в качестве временной формы (Gramatyka PAN 1984; Štícha et al. 2013), хотя он продолжает существовать в пассивной компетенции чехов и поляков, так как данная форма активируется только в определенном виде текстов и в определенных контекстах (см. Митриновић 1995: 250).

Во многих из приведенных исследований подчеркивается, что для ППФ в славянских языках и шире типично «антирезультативное значение» (Плунгян 2001), т. е. данная форма указывает на отклонение от «условной нормы» ${ }^{1}$, когда отсутствует нормальное осуществление запрограммированной ситуации (Храковский 2015: 291).

Необходимо подчеркнуть, что ППФ в славянских языках является смещенным в прошлое перфектом (Маслов 2004: 441, Недялков 1983), для которого характерен «ретроспективный сдвиг» (Плунгян 1998). Подобно перфекту, он сочетает в себе две референтные точки на условной оси времени - время события и другой прошедшей ситуации, относительно которой ориентируется это событие. Поэтому ППФ может рассматриваться как динамический (акциональный), в случае профилирования события, либо статальный (результативный), когда профилируется результат. В его семантике также четко проявляют себя три различные перспективы наблюдения за ситуацией: а) ретроспективная актуализация ситуации в „прошлом второй степени" из перспективы момента речи; б) сообщение о результате ситуации с синхронной перспективы наблюдателя, находящегося в «прошлом первой степени»; в) проспективное профилирование ситуации с позиции наблюдателя, находящегося в «прошлом второй степени», то есть во времени события, выраженного ППФ.

Ретроспективная актуализация является основной чертой динамического ППФ, в таком случае он используется в нарративе для отхода от продвижения основной тематической линии повествования (Маслов 2004: 441), а также в качестве создания «ситуационного фона» для других отдаленных событий (Ивић 1980). Именно с позиции момента сообщения происходит передвижение обозначаемой ситуации «назад по временной оси» (Плунгян 1998; Петрухин, Сичинава 2006: 205). Синхронная перспектива профилирует состояние, возникшее в результате предшест-

\footnotetext{
${ }^{1}$ «Говоря об условной норме, мы имеем в виду, что предельное действие, начавшись, завершается результатом, а непредельное действие просто прекращается» (Храковский 2015: 291).
} 
вующей ситуации, либо событие, положившее конец ее развитию. В таком случае ППФ оценивается как статальный, результативный. На «результирующее состояние в прошедшем» (Петрухин, Сичинава 2006) ППФ обратили внимание сербские и хорватские лингвисты (Brabec и др. 1952: 227; Сладојевић 1966: 58; Стевановић 1968: 130; Стојановић 2017), так как данное значение продолжает оставаться актуальным для ППФ в этих языках. Проспективное профилирование последующей ситуации имеет место, если речь идет о ППФ, обозначающем прошлое ирреальное условие, «контрафактивном ППФ» (Плунгян 2004; см. также см. Fleischman 1989; Dahl 1997). Такой ППФ отмечен в украинском и болгарском языках (если иметь ввиду только славянские) (см. Попович 2012; 2018 в печати).

Результативный ППФ указывает на ситуацию: а) с неактуальным результатом; б) с результатом, который не удовлетворяет; в) с отсутствующим в момент описываемого события, но ожидаемым результатом (при отрицании и наличии темпорального маркера); г) с аннулированным результатом: (1) (серб.) Лицем на Ђурђев дан густа магла бјеше покрила ломне Куче (Стевановић 1974/ С. Матавуљ); (2) (болг.) Тя беше изпълнила всички условия, за да има онова, което иска, но все пак го нямаше (www.highviewart.com); (3) (срп.) Снијег још није био пао кад стриц дође из затвора (Танасић 2005/М. Лалић); (4) Она се трже од тих речи. За часак је била заборавила да је њихов брак под уговором од три месеца (М. Јаковљевић).

Динамический ППФ может выражать прерванную начинательность и предначинательность ситуации, когда она: а) начата, но из ряда причин не осуществлена; б) запрограммирована, но не начата, ср.: (5) (укр.) Чапчик уже почав був обурюватись на літунів, але тут його перебив Супрун (М. Хвильовий); (6) (укр.) Я вчепився одною рукою в батькові штани, другою за шапку і хотів був казати своє ім'я, та голосу не стало (О. Довженко). Конструкции последнего типа чаще встречаются в восточнославянских языках, к ним можно отнести и русские конструкции с частицей было (Barentsen 1986; Храковский 2015).

Динамический ППФ выполняет прежде всего функцию актуализатора другой информации, поданной на его фоне. В частности, такая функция типична для сербских форм ППФ несовершенного вида (НСВ). В ориентации сербского имперфективного ППФ на передачу фоновой информации, можно усмотреть причину его вытеснения перфектом. Маркированность временной формы в смысле ее использования для передачи фоновой информации является закономерной фазой в преобразовании ее статуса - вытеснения или перехода в ирреалис (Сичинава 2004). В современном сербском языке ППФ НСВ встречается чаще всего в неассертивных придаточных относительных и их парцеллятах, которые, как правило, не используются для ввода новых сообщений и сохраняют «консервативные» грамматические формы (Bybee et al. 1994: 230-231), ср.: (7) То су у стварном смислу биле ,златне године" лингвистичке науке ... и године лингвистичких ратова што су се понајвише управо и били водили око статуса семантике у лингвистичкој науци (М. Радовановић 2009: 70); (8) Позвао сам Оскара. Управо је био завршавао кајгану са шунком (М. Бобић-Мојсиловић 2011: 101). Частотность употребления ППФ НСВ в современном сербском языке настолько низкая, что некоторые исследователи говорят об образовании форм ППФ в сербском языке только от глаголов СВ (Танасић 2009: 66). 
У сербского ППФ СВ отмечен ряд стилистических и дискурсивных функций, что сказывается на особо частом использовании данной формы для ввода дигрессий и маркирования начала нового топика (см. подробнее в: Поповић 2012).

В СПП с придаточным времени формы сербского ППФ по-прежнему выступают в качестве грамматического показателя таксиса предшествования либо следования, в зависимости от того, какая ситуация обозначена этой временнной формой - зависимая или главная. В большинстве случаев ППФ в данной функции можно заменить перфектом в сочетании с темпоральным маркером већ (уже) (см. Поповић 2012)

В болгарском языке ППФ выполняет, кроме таксисных, антирезультативных и дискурсивных функций, присущих сербскому ППФ, и ряд модальных и эвиденциальных функций (см. Мовчан 2015; Куцаров 2007: 302, 313; Поповић 2018 в печати). Расширение семантической зоны ППФ в направлении модальности и эвиденциальности способствует активному употреблению данной формы во всех регистрах болгарского языка и подтверждает вывод о развитии семантики сверхпрошлого времени в сторону ирреалиса как закономерного во многих языках мира (Dahl 1985: 145-146).

В упомянутом исследовании по ППФ в славянских языках (Барентсен 2015) находим интересное замечание о том, что по количеству форм ППФ в переводах художественных произведений с английского на современные славянские языки (данные основаны на поиске в корпусе Amsterdam Slavic Parallel Aligned Corpus) на втором месте после болгарского находится верхнелужицкий язык ${ }^{2}$ (ibid.: 156).

Исследование показывает, что ППФ действительного залога используется в верхнелужицком в придаточных относительных, а также для обозначения отхода от главной линии повествования³ : (9) W Egyptowskej so bórze na to třo zarjadnicy zběhnychu hromadźe z Taharku, kotrehož bě do Nubiskeje wutlóćil (Klíma 1988: 69);

Если рассматривать распределение форм и функций ППФ в славянском континууме, можно заметить следующую закономерность. В зоне наибольшей распространенности ППФ (условимся называть ее южнославянская зона ППФ, в которую входят болгарский, македонский, сербский и хорватский) данная временная форма сохраняет таксисную функцию сходно частотности ее употребления. Болгарские лингвисты настаивают именно на таксисной функции болгарского ППФ, а также на функции обозначения результативности в прошедшем (см. Куцаров 2007: 260; Ницолова 2008: 301-304). В сербском языке на первое место, вместе с таксисной, выдвигаются функции аннулирования результата ситуации и создания ситуационного фона (Ивић 1980; Танасић 2005; Поповић 2012). В западной части славянского континуума (польском, чешском, словацком и словенском) ППФ утрачивает свою результативно-темпоральную специфику и вытесняется другими формами, однако

\footnotetext{
${ }^{2}$ Русские варианты текстов, в которых совершен поиск, имеют объем 297.000 словоупотреблений (примерно 1000 печатных страниц). А. Барентсен указывает, что в таком объеме корпуса найдено 1826 форм ППФ в болгарском языке, 1127 употреблений в верхнелужицком, 309 в хорватском, 273 в македонском, 169 в сербском, 89 в словенском, 24 в украинском и 6 в белорусском. При этом, автор отмечает, что «примеры в данных украинских и белорусских переводах чаще всего относятся к типу, соответствующему русской конструкции с частицей было («прерванность ситуации»)» (Барентсен 2015: 156).

${ }^{3}$ На 100 стр. анализируемого перевода было найдено 7 форм ППФ действительного залога: 3 - в относительных придаточных, 2 - в дигрессивных отступлениях, 1 - для обозначения нового топика, в начале абзаца, и 1 - в таксисной конструкции.
} 
используется в качестве экспрессивно-стилистического средства. ППФ в лужицкосербском, несмотря на данные о его повышенной частотности (Барентсен 2015), преимущественно используется с целью отклонения от линии повествования, а также обозначения «сдвинутой в прошедшее» результативности. ППФ в восточнославянских языках имеет яркую антирезультативную окраску, указывая на ситуацию запрограммированную, но из ряда причин не осуществленную, и служит для создания ситуационного фона, изредка выполняя в украинском языке таксисную функцию, преимущественно, в придаточном относительном (см. Попович 2012), а в белорусском выражает прош. результативность ${ }^{4}$. У русской реликтовой формы с частицей было спектр разнообразных функций ППФ сведен на выражение прерванной начинательности и предначинательности ${ }^{5}$.

\section{0 Омонимия граммем страдательного залога}

Временные формы глагола, как известно, могут выступать в конструкциях с действительным и страдательным залогом. В некоторых славянских языках, например в сербском или болгарском, для каждой временной формы грамматики выделяют две залоговые формы - актива и пассива (Пипер, Клајн 2013: 400-401; Куцаров 2007: 350; Ницолова 2008: 238).

В восточнославянских языках залог влияет на категорию времени (Храковский 2015a), так как в страдательном залоге существует форма настоящего времени у глаголов как несовершенного, так и совершенного вида, а в действительном - только несовершенного вида. С другой стороны, форма ППФ, которая в действительном залоге выделяется в грамматиках украинского языка (см., напр., Русановский и др. 1986, Вихованець, Городенська 2004: 253), а в некоторой степени и белорусского, при описании форм страдательного залога в данных языках не упоминается. Подобным способом обстоит дело и в верхнелужицком, словенском и словацком языках, грамматики которых упоминают только активный залог ППФ (Šewc 1968: 200-201; Toporišić 1976: 335-336; Dvonč et al. 1966: 4776). Как уже было указано,

\footnotetext{
${ }^{4}$ Например, в грамматике белорусского языка Бранислава Тарашкевича (1929 г). форма ППФ подана как запрошль час, напоминающий по форме севернорусский результатив или перфект (Трубинский 1983; Соболев 1988) с глаголом-связкой в форме прошедшего времени, что, собственно, и соответствует плюсквамперфектной семантике: «Часамі здараецца час запрошлы: я быу зрабіуциы, прынёсшы, пайшоўшы і т. д. (перш, чымся што другое здарылася)» (Тарашкевіч 1929: 76). При этом автор грамматики подчеркивает именно таксисную функцию ППФ, а не указание на прерванное действие, типичное, по мнению исследователей, для ППФ в современном белорусском языке (см. Барентсен 2015: 156). Примеры употребления таких страдательно-причастных форм можно услышать в разговорном белорусском языке и сегодня, ср. «Мой тата быў пайшоўшы на вайну і быў дайшоўшы ў Германію» (10.06.2014, https://by-mova.livejournal.com).

${ }^{5}$ По-другому обстоит дело с ППФ в русских говорах, в которых представлены формы и значения данной граммемы, напоминающие украинские и белорусские (см. Шевелева 2007).

${ }^{6}$ Интересным фактом является то, что в академической грамматике словацкого языка граммемы пассива подаются для всех трех времен (настоящего, претерита и будущего), но не и для ППФ. С другой стороны, в качестве пассива претерита собственно и представлены формы пассива ППФ (antepréterita): bol, -a, -o som volaný -á, -é и т. д., хотя в примерах к разделу подается пассив претерита: bola prenasledovaná и пр. (Dvonč et al. 1966: 476), что свидетельствует о смысловом и формальном смешении обеих граммем
} пассива. 
в академических грамматиках чешского и польского языков ППФ в качестве отдельной временной формы не упоминается ни в одном из залогов (Gramatyka PAN 1984; Štícha et al. 2013).

Наличие у глагола граммемы страдательного залога детерминируется лексемой глагола, точнее, ее принадлежностью к определенному акциональному классу предикатов, прежде всего к классу предикатов действия (Храковский 2015a: 3). Однако не у всех временных форм есть одинаковый набор языковых средств для выражения пассива. Иногда формы пассива отличаются своеобразной омонимией, так как у одних и тех же пассивных граммем определяется разное временное значение в зависимости от контекста. Сербские лингвисты рассматривают пассивные граммемы либо как параллельные активным граммемам формы, в которых вместо активного причастия в составе перфекта (је назидао) или плюсквамперфекта (је био назидао) употребляется страдательное - в составе перфекта (је назидан) и плюсквамперфекта (је био назидан) (см. Стевановић 1956: 212; Милошевић 1973), либо как формы, в которых временной показатель глагола-связки, как бы, смещается „на один градус" - презенсу связочного глагола в составе перфекта действительного залога в перфекте страдательного залога соответствует перфект связки: Hanucaла сам: COP.PRS писмо јуче - Писмо је било: COP.PRF написано јуче. Последнее ведет к совпадению форм причастного пассива презенса и перфекта и, в свою очередь, перфекта и ППФ, ср.: пассив перфекта - Они су били осуђени на смрт; пассив ППФ - Они су били осуђени, а после рехабилитовани (Пипер, Клајн 2015: 407). Чтобы установить различие между данными временными формами в пассиве, необходима поддержка контекста.

Если раньше связка типа беше показывала тенденцию к употреблению в составе результативного ППФ, а типа је био - в составе динамического ${ }^{7}$, то на современном этапе такая специализация не наблюдается, так как перфект связки вытесняет форму имперфекта, которая часто приобретает стилистическую окраску (Митриновић 1995). Более того, постепенный переход сербского перфекта в неопределенное прошедшее время (см. Стојановић 2017) привел к нивелированию перфектной семантики связки, что, в свою очередь, становится причиной постепенного превращения сербского ППФ со связкой је био в пассив претерита, который, подобно восточнославянскому, выражает значения ППФ только с опорой на контекст.

Подобным образом обстоит дело и в болгарском языке, в котором пассивная граммема ППФ - «страдателно относително резултативно време (пасивен плусквамперфект)», по мнению исследователей, указывает на пассивное отношение субъекта к результату действия относительно точки отсчета в прошлом, без указания на одновременность либо разновременность ситуаций (Куцаров 2007: 350; Ницолова 2008: 238). Хотя связки типа бяме и бе функционируют в составе болгарского ППФ страдательного залога одновременно, нельзя не заметить закрепление за ними определенных функций. Аорист связки (типа бе) передает ударную информацию, а имперфект (типа беше) чаще употребляется для сообщения фоновой или

${ }^{7}$ Ср.: Бјеху ми купили ново одијело - за сахрану, али ја га обукох најзад, и онда сам брзо оздравио (С. Танасић 2005: 413/М. Лалић); А кад су две групе, велика везирова и мала Давилова, биле одмакле нешто више од пола миље једна од друге, један од везирових коњаника одвојио се, као стрела појурио и брзо стигао Давила и његову пратњу (ibid.). 
ранее упомянутой информации, ср.: (10) Заглавие статьи: Кинофестивальт в Кан бе открит при безпрецедентни мерки за сигурност; (11) Начало статьи: В Кан започва 70-тото издание на кинофестивала. Той беше открит от актрисата Лили-Роуз Деп и иранският режисьор Асгар Фархади (m.btvnovinite.bg 17.05.2017).

Как указано в грамматике Хинца Шевца, у ППФ в верхнелужицком языке две залоговые формы - действительная и страдательная (Šewc 1968: 178-179, 201). В исходной диатезе ППФ формируется с помощью имперфекта связки типа běch и $l$-формы, а в пассивной - с помощью связки типа $b u$, произошедшей од основы аориста, и пассивного причастия. Темпоральная парадигма пассива описана таким же образом, как и в сербском языке, т.е. причастный пассив настоящего времени не выделяется, а пассивом перфекта считаются причастные формы со связкой być в настоящем времени: Wobjed je zvarjeny (Šewc 1968: 201). Форма аориста той же связки с особой основой $b u$ (+ страдательное причастие) соответствующим образом может соотноситься с аористом и ППФ действительного залога: (12) Serbski dom bu 1956 dotwarjeny; (13) Pod Stalingradem buchu fašistiske wójska na smjerć poražene. (Šewc 1968: 201); (14) Wot maćerje a pod jeje stajnym wliwom wotćahnjeny bu z njeho nadpřerěznje zdźěłany knježićel, wo čimž jeho swójske napisy a wosebje zarjadowanje hoberskeje knihownje w Niniwje (XI. kap.) swědča (Klíma 1988: 69).

Темпоральная дифференциация данных значений, связанных с указанием на временной план прошедшего, по-видимому, целиком основана на контексте, определяющем семантику конкретной формы пассива. Корпус верхнелужицкого языка, а также опрос информаторов, показывает, что в современном верхнелужицком распространена и страдательная форма ППФ со связкой типа b̌̌še, сp.: (15) Hdyž smy přišli, wšitko běše hižo zakónčene; (16) To začuće běše hižo dołho potłóčene, ale so znowa pokaza z noweju mocu (Информатор); (17) W najlěpšim padźe běchu někotre hasy znutřka měšćanskich nasypow, kotrež běchu za swjatočne procesije postajene, z cyhelemi wudłóžbjene a z asfaltom wulate (Klíma 1988: 90). Такой форме, по-видимому, свойственно выражение результативного значения в прошедшем (17) либо указание на аннулированный результат (14-15).

Исследования по ППФ в современном украинском языке (Крижанівська 2001, Ярмак 2010; Попович 2012; Поповић 2012; Movchan 2014; Мовчан 2015 и др.) дополняют выводы, сделанные в работе (Барентсен 2015). Однако исследователи не обратили внимание на логичный вопрос: если существует ППФ действительного залога, что соответствует ему в страдательном? Ср.: (18) Я була посадила кілька кущів бузку. То вони їх викорчували, бо доріжки зробити треба. (Газета, 13.01.2012); (19) Мною було посаджено кілька кущів бузку. Как показано в примерах (18-19), с действительным залогом ППФ соотносится причастный пассив прошедшего времени. В украинском языке он часто представлен так называемым «ленивым пассивом» с прямым дополнением (Плунгян 2011: 266-270).

В русском языке такому пассиву соответствует личная страдательно-причастная форма со связкой в форме прош. времени. Как известно, А. В. Бондарко рассматривал русские аналитические причастно-страдательные формы типа Cтол накрыт и Письмо отослано в качестве статального и акционального перфекта (Бондарко 1990: 43-45). В связи с этим совершенно логично, что если причастно-страдательную форму употребить со связкой в форме прош. времени, она выражает, в соот- 
ветствующем контексте, типичное для ППФ значение (перфект + предшествование, результатив + антирезультативность): Стол был накрыт, до того как пришли гости; Письмо было написано, но не отослано. Если рассматривать такие конструкции с точки зрения плюсквамперфектной нагрузки, то она проявляет себя в таксисных конструкциях предшествования, а также при описании ситуаций, отклоняющихся от условной нормы, ср.: (20) Когда был открыт замаскированный вход и они увидели американца, генерал воскликнул (Д. Доценко, НКРЯ). Если в примере (20) употребить форму причастного пассива без глагола-связки, значение следования во времени ситуаций изменяется в пользу одновременности.

Пассивное причастие со связкой в форме прошедшего времени в русском языке может указывать и на аннулированный результат ситуации в прошедшем. Более того, причастие без глагола связки в таком случае употребить нельзя, в отличие от конструкций с результативным значением, в которых оба причастия взаимозаменяемы. Ср.: (21) Картина была потеряна, а затем ее нашли; (22) *Картина потеряна, а затем ее нашли; (23) Церковь (была) построена в 1763 году.

Подобную ситуацию наблюдаем и в других севернославянских языках. В польском языке для выражения нивелированного результата используется пассивное причастие со связкой być (24), тогда как прошлое результативное значение чаще выражает вспомогательный глагол zostać (25). Cр.: (24) Wieżowiec Grenfell Tower, który spalit się z wtorku na środę, był zbudowany w 1974 roku i znajdowało się w nim 120 mieszkań (www.tvp.info, 14.06.2017); (25) Pierwszym budynkiem nowo budowanego kompleksu jest WTC7, który został zbudowany w latach 2004-2006 i stoi na miejscu swego poprzednika (https://pl.wikipedia, 14.06.2017.).

Разнообразие форм вспомогательных глаголов в формах ППФ является отличительной чертой данной временной формы, причем как в синхроническом, так и в диахроническом аспекте.

\section{0 ППФ типа „Пассивное причастие + аорист вспомогательного глагола” в древнерусском языке}

В содержательной работе, посвященной происхождению условного наклонения в славянских языках, Дмитрий Сичинава затрагивает вопрос о функционировании разных временных форм глаголов-связок в типологическом аспекте (Сичинава 2004). В частности, автор, ссылаясь на (Foulet 1925, Squartini 1998), пишет о ППФ с аористом вспомогательного глагола, противопоставленном ППФ с имперфектом связки по признаку результативности (первый означал чистое предшествование в прошедшем, второй - с бо́льшим акцентом на результирующее состояние в прошедшем) (Сичинава 2004: 299). В той же работе, ссылаясь на (van Schooneveld 1959: 123-140; Goeringer 1995), автор пишет об аналитических формах ППФ с аористом и имперфектом в книжном древнерусском, где связка в форме типа ходиль бъ чаще всего рассматривается как форма имперфективного аориста глагола быти, параллельная быl(cmb) (van Schooneveld 1951), а связка в форме типа ходиль бяме - как форма имперфекта (Сичинава 2004: 299). 
Совершенно логично, что аналогичные формы - с пассивным причастием и вспомогательным глаголом типа бъ (именно вспомогательным глаголом, а не связкой, см. об этом подробнее в: Шевелева 2007), выражали и плюсквамперфектное значение. Возникает вопрос? Могла ли форма типа быl(c) положен выполнять ту же функцию? Если могла, то каково было функциональное распределение между формами пассива типа бъ положенъ и бы (c) положен? Для того чтобы ответить на перечисленные вопросы, обратимся к тексту апракосного Добрилового Евангелия, церковнославянского памятника древнерусского извода, датируемого 1169 годом ${ }^{8}$.

В основательных грамматических комментариях к факсимильному изданию этой рукописи (Добрилове 2012), составители указывают, что форма вспомогательного глагола бъ встречается в тексте 239 раз, в том числе в составе ППФ 8 раз: нњ БЊ прншєАъ (И VI:17, 13; И XI:30; 195 об. $)^{9}$, в ь прншла (И VII:30, 20; И VIII:20, 20 об.), СъБьралъ сА вь (М I:33, 85), нұГыБ九ъ вь (Л ХV:24, 172 об; Л ХV:32, 173), в屯 прнсталъ (Л XXIII:51, 186 об.). В результате сплошной выборки нами зафиксирован еще один пример: вь далъ (Л ХХІІІ:47, 183). Во всех случаях, кроме одного, приведенные примеры ППФ употребляются в своего рода отступлениях от повествовательного тока, объясняющих событие основной тематической линии. Два раза ППФ указывает на отсутствующий в момент описываемого события результат, но ожидаемый и достигнутый позже, что подчеркивается с помощью темпорального маркера оү(хє) (еще): нъ оү въ прншєлъ. Значение аннулированного результата зафиксировано всего один раз: ндгыБлъ Бь н оврьте са (Л XV:32; 173).

Плюсквамперфетные формы пассива в комментариях не оговариваются. Однако глагол-связка бъ сочетается и со страдательными причастиями. В частности, в результате сплошной выборки в тексте Добрилового Евангелия было обнаружено следующие формы: въ нсьчєнъ (M XV:46, 13 об., 236; Л XXIII:53, 187; Мт XXVII:60, 240), отвалєнъ вь (M XVI:4, 14, 241 об.), въ положєнъ, (M XVI:5, 14, 241 об.; XXIII:53, 187), въ данъ (И VII:39, 39 об.), нє въ прославлєнъ (И VII39, 39 об.), въ въспнтанъ (Л IV: 16, 108), вь напнсано (Л IV:17, 108; М XV:26, 233; Л ХХІІІ:38, 234 об.; И ХІХ:19-20, 247 об., 248), въ въвєржєнъ (Л ХХІІІ:19, 185 об.), а также близкие им формы со связкой вє: званъ Бє (И II:2, 9.об.), вє положєнъ (И ХІХ:41, 236 об.). Примечательно, что ни один из выделенных примеров не соотносится с пассивом ППФ в греческом тексте $^{10}$, однако всем примерам пассива ППФ с формой бњ из Добрилого Евангелия соответствует ППФ с вспомогательным глаголом беше в сербском переводе ${ }^{11}$. Данные формы встречаются в таксисной функции (zванъ ьъ), а также в сверхпрошлом значении (Плунгян 2011: 358), то есть для выражения результата, который был актуален в прошлом (вЊ въєєжєнъ, вЊ напнсано), либо результата, который не был достигнут в момент описываемого события, но ожидаем и достигнут позже (последнее подчер-

\footnotetext{
${ }^{8}$ Вопрос о конкуренции вспомогательных глаголов в причастном пассиве древнерусского языка, а также восточнославянских языков 16-18 веков, составляет тему отдельного исследования и в настоящей статье затрагиваться не будет, см. (Шевелева 2007).

${ }^{9}$ В скобках подается фолиация. Обозначение об. значит: на обратной стороне листа. Фолиация подается согласно факсимильному изданию (Добрилове 2012).

${ }^{10} \mathrm{~B}$ цитируемой работе указано, что из 66 примеров ППФ во всех текстах Евангелий на греческом языке обнаружено всего 5 пассивных образований (Барентсен 2015: 137).

${ }^{11}$ Текст сербского перевода, а также параллельные стихи греческого и русского переводов взяты с портала Свето писмо online <https://pouke.org/svetopismo/> 25.03.2017.
} 


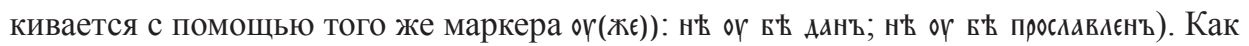
видим, набор значений у форм типа въ данъ тот же, как и у ППФ действительного залога типа ьъ далъ (см. выше).

В последующих переводах на славянские языки перечисленные страдательнопричастные формы представлены по-разному. Например, в двух переводах на современный украинский язык находим как ППФ действительного залога, так и страдательно-причастный пассив со вспомогательным глаголом був: (26) Він воскрес - нема Його тут! Ось місце, де Його поховали були (M XVI: 6; Огієнко 1955: 69²); (27) Він воскрес; нема Його тут. Ось місце, де Він був положений (M XVI: 6; www. sophiachurch.com). Страдательная форма в приведенном примере (26) соотносится с соответствующей церковнославянской формой со вспомогательным глаголом бъ: (28) въста нҺсть сАє сє МҺсто ндє жє ББ положєнъ (M XVI: 6; Добрилове 2012: 14).

У формы вь положєнъ в примере (28) антирезультативное значение. Ангел говорит женщинам, что Христос воскрес, указывая на пустое место, где раньше находилось его тело. Страдательная форма обозначает ситуацию, чей результат аннулирован другой ситуацией, т.е. выполнят типичную для ППФ функцию. Если сравнить данный перевод Евангелия с его аналогами на древнем чешском языке, то в соответствующем месте, как и в переводе на украинский язык (см. 26), также употреблен ППФ исходной диатезы: (29) Kterýžto řekl jim: Nebojte se. Ježíše hledáte Nazaretského ukřižovaného. Vstalt’ jest, nenít' ho tuto; aj, místo, kdež jej byli položili (M XVI: 6; Bible kralická 1579-1593, 1616 ${ }^{13}$ ). В переводах на польский и украинский языки того же периода (XVI век) употреблена безличная конструкция с причастием на -но и лпричастием глагола быть (упомянутый ,ленивый пассив”): (30) A on mówi im: Nie zdumiewajcie się; Jezusa szukacie Nadzarethskiego, onego ukrzyżowanego; wzbudzon jest, nie masz go tu; oto miejsce, gdzie go było położono (M XVI: 6; Rakow.15774); (31) а Фнь рекль имь. не боитє(с). іса ищєтє нзарАнина пропАтого. всталь єсть. и нє єсть єго тоу(т). алє тото є(ст) мъсцє гдє єго было положєно (M XVI: 6; Пересопницьке Свангеліє 1556-1661/2011: 196). ${ }^{15}$ В словацком переводе XX века, как и в украинском, также находим ППФ действительного залога: (32) Ale on im povedal: Nel'akajte sa! Hl'adáte Ježiša Nazarénskeho, toho ukrižovaného. Vstal, niet ho tu. Hl'a, miesto, kde ho boli položili (M XVI: 6; Roháček, $1936^{16}$ ).

В русском и польском переводах XX века употреблена пассивная конструкция со вспомогательным глаголом быть в прошедшем времени, которая функционально соотносится с ППФ: (33) Он воскрес, Его нет здесь. Вот место, где Он был положен (M XVI: 6); (34) Lecz on rzekł do nich: Nie bójcie się! Szukacie Jezusa z Nazaretu, ukrzyżowanego? Wstał, nie ma Go już tu. Oto miejsce, gdzie był złożony (M XVI: 6; Warsz.Praska 1974).

В сербском переводе в данном случае употреблен аорист, соответствующий такой же форме в тексте Евангелия на греческом: (35) није овдје, ево мјесто гдје га

\footnotetext{
$12<$ https://books.google $>1.11 .2017$.

${ }^{13}<$ www.etf.cuni.cz/ rovnanim/bible/ $>1.11 .2017$.

${ }^{14}$ Все приведенные цитаты из разных переводов Евангелия на польский язык взяты из:

$<$ http://bibliepolskie.pl/zzteksty_wer.php?book=41\&chapter=16\&verse=6\&tlid=8>1.11.2017.

${ }^{15}$ Фолиация подана согласно факсимильному изданию (Пересопницьке Свангеліє 2012).

${ }^{16}$ Biblia, preklad Jozefa Rogáčka, 1936

$<$ http://www.obohu.cz/rohacek/rohacek.php?kap=16\&k=Mk>1.11.2017.
} 


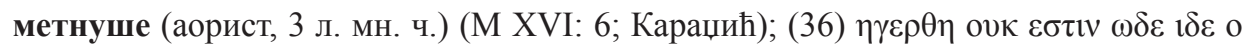

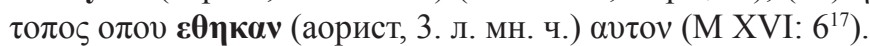

Очевидно, церковнославянская форма бь положенъ могла соотноситься и с пассивом аориста, однако ее интерпретация в качестве ППФ исходной диатезы в переводах на украинский, чешский и словацкий указывает, что значение аннулированного результата предшествующего действия, выражается в этих славянских языках именно с помощью ППФ. Поэтому пассивную форму претерита был положен в таком контексте логично рассматривать в качестве ППФ.

Для указания на временной план прошлого в конструкции пассивной диатезы также использовалось страдательное причастие и вспомогательный глагол в аористе. Такая форма передавала прежде всего аористическое значение, часто указывала на быструю смену ситуаций, см. (37), но и на ситуацию непосредственно повлиявшую на последующую, находящуюся в фокусе высказывания, т.е. имела перфектное значение в прошедшем, см. (39). В тексте Добрилового Евангелия данную функцию выполняет конструкция с вспомогательным глаголом вы. В частности, в результате сплошной выборки зафиксированы следующие примеры причастного пассива: кы посланъ (И І:6, 2), съзьдана Бы (Л IV:26, 109), попрано вы (Л VIII:5, 120 об.), погревєнъ Бы (Л XVI:22, 125), окАеветань вы (Л XI:1, 139 об.), въпрошєн вы (Л XVII:20, 141 об.), положєно вь продана вы (И ХІІ:5, 197 об.), пороүганъ вы (Мт II:16, 254 об.), пръданъ вы об.), прнчьтенъ Бысть (232 об.). Соответствующим образом, в сербском переводе им соответствует не плюсквамперфект, а аорист (38) или перфект (40), преимущест-

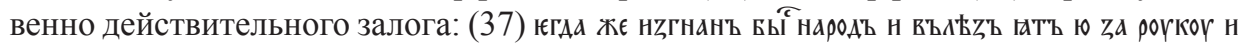
въста дв̆ц (Мт IX:25; Добрилове 1164: 62 об.); (38) А кад истјера народ, уђе и ухвати је за руку, и устаде дјевојка (Мт IX:25; Караџић); (39) тогда нродъ вндьвъ ғако пороүганъ

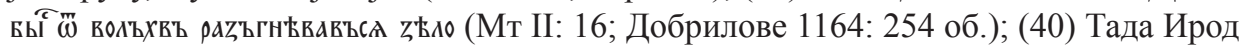
кад видје да су га мудраци преварили, разгњеви се врло (Мт II: 16; Караџић).

Пассиву с 6 в в церковнославянском языке конкурирует причастная форма со вспомогательным глаголом БЊашє/БЊґшє. В тексте Добрилового Евангелия она встречается в составе страдательно-причастной конструкции только в одном примере съzьданъ БАшє (Л IV:29, 109). Форма употреблена для обозначения неактуального результата в придаточном относительном, то есть по значению может рассматриваться в качестве пассива ППФ.

Причастие типа быль в Добриловом Евангелии встречается только в функции связки в именном сказуемом. ППФ с данным причастием, так называемый новый ППФ, фиксируется в древнерусском языке уже с начала 12 века и рассматривается исследователями как форма из двух самостоятельных претеритов (Шевелева 2007: 218). Подытоживая вышесказанное, приходим к выводу, что страдательно-причастные формы в церковнославянском языке выражали разные значения - в зависимости от вспомогательного глагола 61 или бы $(\mathrm{cmb})$. Ни одна из этих форм не соответствовала ППФ в греческом языке и не являлась специализированной таксисной, хотя обе могли указывать на предшествование. Формы со вспомогательным глаголом 61 передавали значение результативности в прошедшем, в том числе значение от-

${ }^{17}<$ https://pouke.org/svetopismo/> 25.03.2017. 
сутствующего, но ожидаемого (при отрицании), либо аннулированного результата. Форма с 6 bl(c) выражала аористическое значение, но могла передавать и перфектное значение, указывая на актуальность события для ситуации в прошедшем, поэтому в определенных контекстах может приравниваться к акциональному ППФ.

\section{Заключение}

В результате анализа ППФ действительного залога в современных славянских языках и соотносимых с ними форм страдательного залога, а также ретроспективы соответствующих форм в церковнославянском языке древнерусского извода, можем прийти к следующим выводам:

1. Распространение ППФ в славянских языках связано с его функциональным статусом. Чем распространеннее ППФ, тем шире представлены все его функции.

2. Антрирезультативные значения могут быть нескольких типов. Для южнославянских языков типично выражение результата, аннулированного другой ситуацией в прошедшем, а для восточнославянских - отклонение от запрограммированного развития ситуации, ведущее к отсутствию результата.

3. Употребление ППФ в неассертивных контекстах обуславливает его использование для создания ситуационного фона и служит индикатором его постепенного вытеснения другими претеритальными формами.

4. Отличием ППФ является возможность его формирования с помощью разных вспомогательных глаголов. Разнообразие вспомогательных глаголов присуще и соотносимым с ППФ страдательно-причастным формам: беше/ био је - в сербском языке; бяше/бе - в болгарском; bu/bе̌še в верхнелужицком; бъ/ бе, бАше/ бы (c), бы (сть) в церковнославянском (а также их аналоги во мн. числе).

5. Диахронический анализ показывает, что вспомогательные глаголы различного происхождения функционировали в составе страдательно-причастных форм одновременно, но за ними исходно были закреплены разные значения. Вспомогательные глаголы, восходящие к имперфекту, выражали результативное состояние (статальный ППФ), тогда как связки аористического происхождения употреблялись для выражения смены ситуаций и передачи информации, соотносимой с динамическим аспектом ППФ. Отголоски функциональной специализации ППФ с разными типами связок находим в современном болгарском (в большей степени) и сербском языке. Связки имперфективного происхождения, в конкуренции с аористическими, могут также указывать на коммуникативное дефокусирование, т.е. использоватся для оформления ситуативного фона.

6. Л-форма вспомогательного глагола, в силу своей аспектуально-темпоральной неотмеченности, может передавать значения ППФ с опорой на контекст. Наблюдается своеобразная деграмматикализация ППФ действительного залога с лформой вспомогательного глагола, которая становится факультативной, заменимой 
другими темпоральными формами. В страдательном залоге данная связка вытесняет другие, в результате чего исчезает темпоральная специализация формы.

7. Пассив ППФ в славянских языках выражает значения предшествования ситуации в прошлом, результата в прошлом, аннулированного результата, но не прерванной начинательности и предначинательности, так как последние выражаются непереходными глаголами модальной и начинательной семантики.

\section{Лuтература}

Барентсен А. „Наблюдение о встречаемости плюсквамперфекта в славянских языках." Поповић Љ., Војводић Д., Номаћи М. (ур.). У простору лингвистичке славистике. Зборник научних радова. Поводом 65 година жсиота академика Предрага Пипера. Београд, 2015: стр. 135-160.

Бондарко А. В. Теория функциональной грамматики. Темпоральность. Модальность. Ленинград: Наука, 1990.

Вихованець І. Р., Городенська К. Г. Теоретична морфологія украӥнської мови. Київ: Пульсари, 2004.

Загнітко А. П. „Знову давноминулий?” Лінгвістичні студї, вип. 2 (1996): 40-45.

Ивић М. „О значењу српскохрватског плусквамперфекта.” Зборник за филологију и лингвистику, књ. 18, св.1 (1980): стр. 93-100.

Крижанівська О. „Спостереження за вживанням форм давноминулого часу в розмовно-побутовому мовленні." Наукові записки Вінницького держ. пед. ун-ту ім. М. Коиюбинського. Філологія. Вінниця: Видавничий відділ ВДПУ, вип. 3 (2001): стр. 98-101.

Козинцева Н. А. „Плюсквамперфект в армянском языке.” М. Ю. Черткова (ред.). Типология вида: проблемы, поиски, решения. Москва: Языки русской культуры, 1998: стр. 207-218.

Куцаров Ив. Теоретична граматика на българския език. Морфология. Пловдив, Университетско издателство „Паисий Хилендарски”, 2007.

Маслов Ю. С. Избранные трудыл: Аспектология. Общее языкознание. Москва: Языки славянской культуры, 2004.

Милошевић К. „Темпорално значење и синтаксичка вриједност конструкција Сор (praes.perf.) + part.pass. у српскохрватском језику.” Јужнословенски филолог, књ. XXX, св. 1-2 (1973): стр. 423-437.

Митриновић В. „Неколико запажања о плусквамперфекту као средству стилизације текста у „Сеобама” Милоша Црњанског (у оригиналу и пољском преводу дела).” Научни скуп слависта у Вукове дане, књ. 23, св. 2 (1995): стр. 245-254.

Мовчан Я. „Плюсквамперфект в современных славянских языках: на примере болгарского и украинского языков." Trends in Slavic Studies, Москва, 2005: стр. 813-827.

Молошная Т. Н. „Плюсквамперфект в системе грамматических форм глагола в современных славянских языках.” Николаева Т. М. (ред.). Русистика. Славистика. Индоевропеистика: Сб. к 60-летию А. А. Зализняка. Москва: Индрик, 1996: стр. 564-573. 
Недялков В. П. (ред.). Типология результативных конструкиий (результатив, пассив, статив, перфект). Ленинград: Наука, 1983.

Ницолова Р. Българска граматика. Морфология. София: Университетско издателство „Св. Климент Охридски”, 2008.

Петрухин П. В., Сичинава Д. В. „«Русский плюсквамперфект» в типологической перспективе.” Вереница литер. К 60-летию В. М. Живова. Москва: Языки славянской культуры, 2006: стр. 193-214.

Плунгян В. А. „Плюсквамперфект и показатели «ретроспективного сдвига»” В. Ф. Выдрин, А. А. Кибрик (ред.). Язык. Африка. Фульбе: Сборник статей в честь А. И. Коваль. СПб.: Европейский дом, 1998: стр. 106-115.

Плунгян В. А. „Антирезультатив: до и после результата.” Плунгян В. А. (ред.). Исследования по теории грамматики, вып. 1: Глагольные категории. Москва: Русские словари, 2001: стр. 50-88.

Плунгян В. А. „О контрафактических значениях плюсквамперфекта.” Lander Y. А., Plungian V. A., Urmanchieva A. Y. (eds.). Irrealis and Irreality. Moscow: Gnosis, 2004: pp. 273-291.

Плунгян В. А. Введение в грамматическую семантику: грамматические значения и грамматические системы языков мира. Москва: РГГУ, 2011.

Попович Л. „Граматичні та семантичні функції плюсквамперфекта в сучасній українській мові.” Акцентологія. Етимологія. Семантика. До 75-річчя академіка НАН України В. Г. Скляренка. Київ, 2012: стр. 653-673.

Поповић Љ. „Функције плусквамперфекта у савременом српском и украјинском језику." Јужнословенски филолог, LXVIII (2012): стр. 113-145.

Попович Л. „О страдательном залоге плюсквамперфекта в сербском и болгарском языках.” ХІІІ Международни славистични четения: Юбилейна научна сесия в чест на проф. д.ф.н. Руселина Ницолова. София, 21-23. априла 2016. 2018 (в печати).

Русановский В. М., Жовтобрюх М. А., Городенская Е. Г., Грищенко А. А. Украинская грамматика. Киев: Наукова думка, 1986.

Сичинава Д. В. „К типологии глагольных систем с несколькими формами плюсквамперфекта: casus latinus.” Вопросы языкознания, 5 (2003): стр. 40-52.

Сичинава Д. В. „К проблеме происхождения славянского условного наклонения.” Ландер Ю. А., Плунгян В. А., Урманчиева А. Ю. (ред.). Исследования по теории грамматики. Bыл. 3. Ирреалис и ирреальность. Москва: Гнозис, 2004: 292-313.

Сичинава Д. В. Типология плюсквамперфекта. Славянский плюсквамперфект. Москва: Институт русского языка им. В.В.Виноградова РАН, АСТ-ПРЕСС, 2013.

Сладојевић П. О основним временским категоријама употребе глаголских облика у српскохрватском језику. Београд: Научна књига, 1966.

Соболев А.Н. „О предикативном употреблении причастий в русских диалектах.” Вопросы языкознания, 5 (1998): стр. 74-89.

Стевановић М. Функиије и значења глаголских времена. Београд: САНУ, 1968.

Стевановић М. Савремени српскохрватски језик. (Граматички ситеми и књижевнојезичка норма). II Синтакса, Београд: Народна књига, 1974. 
Стојановић С. Функционално-семантичко поље перфектности у руском и српском језику. Докторска дисертација, одбрањена 30.09.2017. на Филолошком факултету у Београду.

Танасић С. „О перфекту и плусквамперфекту имперфективних глагола.” Зборник Матице српске за филологију и лингвистику, књ. 39, св. 1 (1996): стр. 91-97.

Танасић С. „Синтакса глагола.” Пипер П., Антонић И., Ружић В., Танасић С., Поповић Љ., Тошовић Б. Синтакса савременога српског језика, Проста реченица. Ивић М. (ред.). Београд: Институт за српски језик САНУ, Београдска књига, Матица српска, 2005: стр. 345-469.

Танасић С. „Статус плусквамперфекта у савременом српском језику.” Шести лингвистички скуп Бошковићеви дани. Подгорица: ЦАНУ, 2005а: стр. 231-239.

Танасић С. Синтаксичке теме. 2. издање. Београд: Београдска књига, 2009.

Тарашкевіч Ў. Беларуская граматыка для школ. Вільня, 1929.

Трубинский В. И. „Результатив, пассив и перфект в некоторых русских говорах.” Недялков В. П. (ред). Типология результативных конструкиий (результатив, статив, пассив, перфект). Ленинград: Наука, 1983: стр. 216-226.

Храковский В. С. „Плюсквамперфект и конструкция с частицей было в восточнославянских языках." Ватрослав Ягич і проблеми слов'янознавства. Київ, 2015: стр: 287-298.

Храковский В. С. „Русский глагол: иерархия грамматических категорий и их взаимодействие в пассивных конструкциях.” Поповић Љ., Војводић Д., Номаћи М. (ур.). У простору лингвистичке славистике. Зборник научних радова. Поводом 65 година живота академика Предрага Пипера. Београд, 2015а: стр. 777-798.

Шевелева М. С. „Русский плюсквамперфект» в древнерусских памятниках и современных говорах.” Русский язык в научном освещеении, 2,14 (2007): 214-252.

Ярмак В. Семантичний діапазон плюсквамперфекта в романі Драгослава Михаїловича "Коли ивіли гарбузи" та в його перекладі украӥнською мовою. <www. rastko.org $>15.09 .2017$.

Barentsen A. „The use of the particle БЫЛО, in modern Russian.” Dutch Studies in Russian Linguistics, vol. 8 (1986): pp. 1-68.

Bybee J., Perkins R., Pagliuca W. The Evolution of Grammar: tense, aspect and modality in the languages of the world. Chicago, London: University of Chicago Press, 1994.

Brabec I., Hraste M., Živković S. Gramatika hrvatskoga ili srpskog jezika. Zagreb: Školska knjiga, 1952.

Chinkarouk O. „Le Plus-que-parfait dans la phrase complexe (coordination et juxtaposition) en ukrainien moderne." Le Langage et l'Homme, XXXIII, 1 (1998): 39-53.

Dahl Ö. Tense and Aspect Systems. Oxford: Blackwell, 1985.

Dahl Ö. „The relation between past time reference and counterfactuality: a new look.” Athanasiadou A., Dirven R. (eds.). On Conditionals Again. Amsterdam: Benjamins, 1997: 97-114. 
Dvonč L., Horák Г., Miko Ф., Mistrík J., Oravec J., Ružička J., Urbančok M.. Morfológia slovenského jazyka. Ružička J. (red.). Bratislava: Vydatel'stvo Slovenskej akadémie vjed, 1966.

Horák E. „Predmiuly čas v slovenčyne.” Slovenská reč, roč. 29 (1964): 286-298.

Goeringer K. „The Motivation of Pluperfect Auxiliary Tense in the Primary Chronicle.” Russian Linguistics, 19, 3 (1995): pp: 319-332.

Fleischman S. „Temporal distance: a basic linguistic metaphor.” Studies in language, 13, 1 (1989): pp: 1-50.

Foulet L. „Le développement des formes surcomposées.” Romania, 51 (1925): 203-252.

Gramatyka współczesnego języka polskiego IJP PANt.II: Morfologia. R. Grzegorcyzkowa, R. Laskowski, H. Wróbel. Warszawa: Polskie Wydawnictwo Naukowe, 1984.

Movchan Y. „Das Plusquamperfekt im Ukrainischen im Vergleich zum Bulgarischen.” Anzeiger für Slavische Philologie, XLI (2014): 95-117.

Squartini M. Verbal Periphrases in Romance: Aspect, Actionality and Grammaticalization. Berlin: Mouton de Gruyter, 1998.

Šewc H. Gramatika hornjoserbskeje rěče. 1. zwjazk fonematika a morfologija. Budyšin: Ludowe nakładnistwo Domowina, 1968.

Štícha F., Vondráček M., Kolářová I., Hoffmannová J., Bílková J., Svobodová I. Akademická gramatika spisovné češtiny. Praha: Academia, 2013.

Thomas P. L. „Le plus-que-parfait en serbo-croate (bosniaque, croate, monténégrin, serbe) dans une approche contrastive avec le français." Passé et parfait, 6 (2000): $117-131$.

Thomas, P. L. „Плусквамперфекат - жива граматичка категорија савременог српског језика?" Научни скуп слависта у Вукове дане, књ. 33, св. 1 (2004): стр. $111-122$.

Toporišić J., Slovenska slovnica. Ljubljana; Maribor: Založba Obzorja Maribor, 1976.

Van Schooneveld C. H. A Semantic Analysis of the Old Russian Finite Preterite System. S. Gravenhage: Mouton, 1959.

\section{Источники}

Бобић-Мојсиловић М. Оно све што знаш о мени. Београд: Ганеша клуб, 2011.

Добрилове Євангеліє 1167 року. Львів: Інститут української мови; Інститут українознавства НАНУ, 2012.

Довженко О. Зачарована Десна. <http://www.ukrlib.com.ua> 16.08.2017

Јаковљевић М. (Мир-Јам) Самаи у браку. https://books.google.rs/12.12.2017.

Политика. <http://www.politika.rs> 29.01.2018

Пересопнищьке Євангеліє 1556-1561. Дослідження. Транслітерований текст. Словопокажчик. Вид. II, доп. Київ: Національна бібліотека України ім. В. І. Вернадського; Інститут української мови НАНУ; Український мовно-інформаційний фонд, 2011.

Радовановић М. Увод у фази лингвистику. Сремски Карловци; Нови Сад: Издавачка књижарница Зорана Стојановића, 2009.

Свето писмо online $<$ https://pouke.org/svetopismo/>10.11.2017.

Хвильовий М. Майбутні шахтарi.<http://ukrlit.org/> 10.11.2017. 
Klíma J. Ludzó mezopotamiskeje. Po puću starodawneje ciwilizacije a kultury při Eufraće a Tigrisu. Ze słowakšćiny do hornjoserbšćiny: M. Wolf. Bratislava: Nakładnistwo Obzor, 1988

\author{
Људмила В. Поповић
}

\title{
О ПАСИВУ ПЛУСКВАМПЕРФЕКТА У СРПСКОМ И ДРУГИМ СЛОВЕНСКИМ
}

$$
\text { ЈЕЗИЦИМА }
$$

\section{Резиме}

На грађи словенских језика у раду се разматра семантика плусквамперфекта (ППФ), његова заступљеност у савременим словенским језицима, анализирају се темпоралне и друге функције тог облика. Посебна пажња је скренута на облике пасивне дијатезе који су описани као ППФ у граматикама појединих словенских језика или се функционално изједначују са ППФ. Полазећи од корпуса савремених словенских језика, као и превода Јеванђеља на црквенословенски језик староруске редакције, размотрени су облици пасивних грамема који се корелишу са ППФ активне дијатезе. Примећена је појава конкурентних помоћних глагола у саставу ППФ пасивне дијатезе и формулисана је хипотеза о првобитној њиховој специјализацији, која је подразумевала коришћење имперфекта копуле уз резултативни ППФ, а аориста уз акционални. Запажа се одјек такве специјализације у савременом бугарском језику, а донекле, и у српском. Објашњава се потискивање имперфекта помоћног глагола обликом перфекта, који због губитка перфектне семантике прелази у прошло време и узрокује темпоралну неспецификованост претериталних пасивних облика.

Кључне речи: словенски језици, плусквамперфекат, пасив. 